7. Reprod. Fert. (1971) 27, 157-158

\title{
PROCEEDINGS OF THE BLAIR BELL RESEARCH SOCIETY
}

\author{
SGIENTIFIG MEETING, 5TH APRIL 1971 \\ Held at the Royal College of Obstetricians and Gynaecologists, London
}

Edited for the Society by

G. CHAMBERLAIN

Rh iso-immunization following abortion. S. L. BARRon, Department of Obstetrics and Gynaecology, Princess Mary Maternity Hospital, Newcastle-upon-Tyne $\mathcal{N} E 23 B D$, and Sheilagh G. M. Murray, Regional Transfusion Centre, Newcastle-upon-Tyne $\mathcal{N E 4} 6 Q B$.

Previous studies have demonstrated that measurable transplacental haemorrhage (TPH) occurs in association with abortion, and $177 \mathrm{Rh}$ negative women, not already immunized, were studied after therapeutic abortion or curettage following spontaneous abortion. Only ninety-six were successfully traced at intervals of 6 to 14 months after abortion and, of these, forty-eight were primigravidae. The indirect Coombs' test was positive in two patients and, in a further seven, specific anti-D was found by the papainized cell technique. If all cases are included the incidence of immunization was $3 / 48$ in primigravidae and $6 / 48$ in multigravidae.

No relationship was found between immunization and the length of gestation or the measured TPH. Although patients terminated by hypertonic saline had a higher incidence of iso-immunization than those terminated by other methods, the numbers are too small to be of significance. The Kleihauer test appeared to be of no predictive value in this situation. Only further follow-up studies can determine whether or not antibodies detected only against papainized cells are of clinical importance.

Output of oestriol in relation to duration of human labour. J. K. Burns, Department of Physiology, University College, Galway.

Studies on rat myometrial contractibility suggest that oestriol can act as a competitive inhibitor of other oestrogens. A neuroendocrine cycle is suggested to explain the increase in oestriol in human subjects during late pregnancy when the main determinant of the output of oestriol is ACTH; this may be affected by the psychosomatic influences on the hypothalamo-pituitaryadrenal axis.

It is suggested that excess of oestriol in late pregnancy may cause prolonged labour. The output of oestriol has been measured in the third trimester of pregnancy and a correlation found with the duration of the first stage of human labour in multipara. 
Menstrual blood loss and haematological indices. SusAn Cole, Medical Research Council Reproduction and Growth Unit, Princess Mary Maternity Hospital, Newcastle-upon-Tyne NE2 3BD.

Menstrual blood losses have been measured during two consecutive periods in 348 women, over $93 \%$ of the non-pregnant women aged 17 to 45 years in a small Northumbrian mining village.

While the range of losses recorded in this series is similar to that of the population study in Sweden (Hallberg, Hogdahl, Nilsson \& Rybo, 1966), various factors have emerged which appear to influence menstrual loss, and which do not seem to have been recorded previously:

(1) Menstrual loss is related to parity but not to age.

(2) Within broad parity groups, the women who had had heavy babies had larger menstrual losses than those with lighter babies.

(3) There was some evidence that menstrual loss might be related to stature.

The inference is drawn that the size of the uterus and its blood flow are probably partly responsible for the volume of menstrual loss.

Menstrual losses of over $45 \mathrm{ml}$ blood per period are shown to be associated with significant changes in haemoglobin, haematocrit, mean corpuscular haemoglobin concentration, serum iron and iron-binding capacity.

\section{REFERENCE}

Hallberg, L., Hogdahl, A. M., Nilsson, L. \& Rybo, G. (1966) Acta obstet. gynec. scand. 45, 25. 